Available online at: http://proceeding.rsfpress.com/index.php/pss/index

LPPM UPN “Veteran” Yogyakarta Conference Series

Proceeding on Political and Social Science Series (PSS)

Volume 1 Number 1 (2020): 1-8

\title{
Climate Policies in Indonesia's Development Agenda: Why a Carbon Tax is Marginalised
}

\author{
Rakhmindyarto \\ Fiscal Policy Agency, Ministry Of Finance Of The Republic Of Indonesia \\ E-mail address rakhmindyarto@gmail.com
}

\begin{abstract}
Drawing on the results of an exploratory qualitative study based on in-depth interviews involving government executives, politicians, business players, and non-government organisations (NGOs), this paper explores climate policies in Indonesia's national development agenda, including whether a carbon tax could be one of the national priority policy goals. The results suggest that there is heterogeneity in how Indonesian key stakeholders perceive climate policies in Indonesia's development agenda. Indonesian stakeholders are cognisant of the adverse impacts of climate change on social, economic, and environmental aspects. They also acknowledge that having clear and sound climate mitigation policies is required to achieve Indonesia's ambitious GHG emissions reduction target. However, Indonesia's development policy goals are focusing on economic growth, in particular boosting infrastructure investments, reducing poverty and inequality, and job expansion. This makes climate policies are compromised and has created conflicts between Indonesia's development agenda and its commitment to deal with climate change issues. Overall, the study finds that climate policies are incompatible with Indonesia's development agenda, therefore a carbon tax is placed at the bottom of the national policy goals.
\end{abstract}

Keywords: climate policies, carbon tax, development, GHG emissions.

This is an open access article under the CC-BY-NC license

\section{INTRODUCTION}

Although climate change mitigation is the subject of considerable interest among Indonesian academics, policymakers, practitioners, and civil society organizations, the government of Indonesia has marginalized climate policies and has placed them at the bottom of their national development priority agenda. A number of studies on the importance of introducing climate policies to reduce GHG emissions in Indonesia have been undertaken (see, e.g., Ministry of Finance, 2009; Nurdianto and Resosudarmo, 2016; and Yusuf and Resosudarmo, 2015;). However, little empirical evidence exists on why the government of Indonesia considers climate policies to be such a low priority on the development agenda. 
The purpose of this paper is to fill this gap through an exploratory qualitative study that involves Indonesian key stakeholders in the Indonesian climate change context, including government representatives, politicians, business stakeholders, and non-government organizations. The study contributes to prior research in two significant ways. First, it adds to the very limited field studies that have investigated the challenges of introducing a carbon tax in Indonesia. Second, the research might be useful for policymakers to promote a multistakeholder approach in the policy process to avoid policy conflicts at the implementation level.

\section{LITERATURE REVIEW}

A carbon tax is defined as "a tax on fossil fuels in proportion to the amount of atmospheric carbon dioxide that is released when they are burned" (Poterba, 1991, p. 47). As an instrument to reduce GHG emissions, a carbon tax is not a new concept. The theoretical basis of a carbon tax is accredited to Pigou (1932), Baumol and Oates (1971), and Coase (1960) (Guglyuvatyy, 2011). In the environmental policy realm, especially in climate change discussions, a carbon tax is recognized as the foremost policy alternative to address emissions problems (see, e.g., Greenwood, 2009; Lawrence H Goulder \& Schein, 2013; Nordhaus, 2013; Baranzini et al., 2017; Stiglitz et al., 2017;).

While some believe that a carbon tax is an efficient climate policy for reducing GHG emissions, many acknowledge instead that introducing a carbon tax would present a number of political-economic challenges (see, e.g., Hsu, 2012; Wang et al., 2016; Mathur and Morris, 2014; Kerkhof et al., 2008; Verde and Tol, 2009; Bureau, 2011; and Feng et al., 2010). Those studies of introducing a carbon tax and the impacts on the economy found that carbon taxes have regressive impacts on low-income households. A second challenge that emerges when a carbon tax is introduced would be whether a carbon tax decreases competitiveness. Competitiveness effects have become one of the most significant issues when a unilateral carbon tax is introduced ( see Baylis, Fullerton, \& Karney, 2013; Dissou and Eyland, 2011; Fischer and Fox, 2012; Rivers, 2010). Political challenges are the most significant difficulties when the government attempts to introduce a carbon tax (Andrew et al., 2010; Jenkins and Karplus, 2017). These studies show that despite the efficacy, simplicity, and low administration costs, which are the advantages of a carbon tax as discussed above, a carbon tax also poses a number of political constraints.

In Indonesia, there is a number of studies with regard to the potential of introducing a carbon tax. For example, The Ministry of Finance (2009) studied the potential of introducing a carbon tax in Indonesia. Using the Indonesian E-3 CGE model, the results showed that a carbon tax of US\$10/tonne $\mathrm{CO}_{2}$ would reduce GHG emissions from fossil fuel combustion in Indonesia by $10 \%$ in 2020. Yusuf and Resosudarmo investigated the distributional impacts of a carbon tax in Indonesia (Yusuf \& Resosudarmo, 2015). The results showed that the implementation of a carbon tax would not necessarily be regressive. Instead, in contrast to most studies from developed countries, a carbon tax on Indonesia's households would result in a progressive distributive effect.

Those studies show that despite the challenges that the government possibly faces, there is an opportunity for Indonesia to introduce a carbon tax as a climate mitigation policy option. 
The studies also show the positive impacts of a carbon tax on the Indonesian economy, and unlike in developed countries, a carbon tax in Indonesia does not show the regressive impacts. However, these studies have not attempted to understand why Indonesia does not have a carbon tax and how a carbon tax could potentially be introduced given the barriers that the country faces.

\section{RESEARCH METHODOLOGY}

As the aim of the study is to explore stakeholders' perceptions in the area of the policy process, this paper uses the grounded theory method as a strategy to achieve the research objective. An in-depth analysis is explored through this approach based on the dialogue with the participants to obtain data from their experience (Charmaz, 2014; Francis, Chapman and Whitehead, 2016). This method was used to analyze the data collected from 29 Indonesian key stakeholders based on interviews conducted between August 2016 and November 2018 in Jakarta-Indonesia and Adelaide-Australia. There were 29 participants were recruited and interviewed. They are representatives from different organizational backgrounds relevant to the carbon tax policy process. For ethical reasons, their names and official positions are not mentioned here. Instead, specific codes were used for referring to their names and institutions.

\section{FINDING AND DISCUSSION}

\section{IV.1. Indonesia's Focus On Economic Growth}

The current government regime (with Joko Widodo as President) was inaugurated on 20 October 2014. The new administration came into power with a development agenda known as "Nawa Cita" (nine dreams). The "Nawa Cita" was a priority development agenda for the next five years, which was the vision outlined during the presidential campaign. It was then integrated into the National Medium-Term Development goals, consisting of nine development priorities, as follows: (1) Give protection and security to all Indonesian people; (2) Build clean, effective, democratic, and trusted governance; (3) Strengthen local government within an integrated nation; (4) System reform and law enforcement; (5) Improve people's quality of life; (6) Increase productivity and international market competitiveness; (7) Empower the domestic strategic economic sector; (8) National character revolution; (9) Strengthen pluralism and social restoration (Bappenas, 2014).

In the first cabinet meeting with all the ministers at the Presidential Palace on 3 January 2015, President Jokowi expected all his staff members to focus on economic growth and poverty reduction. He further stated that improving regulations and the business climate would increase international credibility for Indonesia. In line with this, the government would continuously seek to identify economic development resources to support better growth.

Similarly, one of the participants identified that the current government regime has been focusing on economic development, as shown in the following statement:

Every time I am writing the speech for the Minister, the key messages are always growth, employment, and equality (Participant I-29). 
As identified by Walker (1986), 'pressure for growth' in modern states is the main reason behind the perspectives of a majority of the interviewees. Most of the respondents explained that Indonesia has been focusing primarily on economic growth. In the Mandiri Investor Forum on 7 February 2018, Sri Mulyani Indrawati, the Minister of Finance, echoed that Indonesia would continue to maintain its growth momentum of 5.1\% in 2017 and expect growth of $5.4 \%$ in 2018 .

\section{Iv.2. A Carbon Tax Will Conflict With The National Development Agenda.}

Most of the interviewees explained that a carbon tax as a climate policy was not regarded as a priority in the development agenda or that it conflicted with the development agenda because Indonesia was in the development phase, which required a focus on economic growth.

Addressing emissions issues is not really in the interest of the government of Indonesia, especially if we are talking about our economic development. Well, emissions reduction is an important issue, but now that is not a top development agenda (Participant I-11).

The quote above shows the stakeholders' perspectives that emissions reduction issues are not a government priority. This demonstrates the conflict between economic development and the environment. In fact, there is a tradeoff between public concern about the environment and the economic situation. According to Mildenberger and Leiserowitz (2017), there is a universal belief among policy analysts and political elites that when a country is in the economic development stage, prioritization of environmental policymaking declines as individuals prioritize short-term economic needs (Mildenberger \& Leiserowitz, 2017). In this context, the selected Indonesian stakeholders perceived that Indonesia is still a developing country; therefore, policymakers have prioritized economic development more than environmental concerns.

A carbon tax as climate policy is not regarded as a priority in the development agenda due to its conflicting position with the national strategic plan, which was established in the 20152019 medium-term development plan. Indonesia has an aspiration to be a global top 10 economy by 2030 . To achieve this ambition, boosting investment is a top national priority. As one of the engines of growth, the investment made up 36\% of economic growth in 2016 and will continue to be the driver of growth until 2030 (Ministry of Industry 2018, Socialisation of Making Indonesia 4.0).

The findings show that Indonesia remains focused on economic growth and that climate policies would compromise growth. Climate policies in Indonesia were considered to be a low priority by Indonesian stakeholders due to conflicts with the economic agenda. While climate policy was considered important for reducing GHG emissions, the selected Indonesian stakeholders perceived that it might not be introduced in the near period. 


\section{IV.3. Infrastructure Is The Key Priority.}

The participants identified that the current government's key priority is infrastructure development. The interview quotes show that the interests of the government have been to develop the infrastructure of the nation:

The current government, the Jokowi regime, is very aggressive in the development of infrastructure. This includes building bridges, roads, buildings, ports, and inter-regional connectivity (Participant I-11).

In the cabinet meeting of 12 April 2015, President Jokowi said: "we cannot delay the priority of infrastructure development. If we delay or slow down, the infrastructure financing will be higher. This is to accelerate our economic development" (iNews T.V., 12 April 2015). The government has accelerated infrastructure development across the Indonesian territories to boost economic growth and to reduce inter-regional development disparities.

Through Presidential Decree number 3/2016 regarding accelerating national strategic projects, 225 infrastructure projects and one electricity project have been chosen as National Strategic Projects. In 2017, another aviation industrial project was added to the list. These will all be funded through the national budget, state-owned enterprises, and public-private partnerships.

The commitment to accelerate infrastructure development has been given the go-ahead by the government at any cost, as stated by the following participants:

Building infrastructure is the development priority of the government, and the damage to the environment is one of the development costs that we must pay (Participant I-08).

To be honest, we haven't yet put in the climate change issues on the development priority agenda. We are still busy with infrastructure development. In the energy sector, look, we still mix our energy policy in the future, and fossil fuel energy will still play a significant role. We cannot deny this because we have an abundant source of coal, so using coal energy is very cheap even though it is dirty (Participant I-15).

One of the national infrastructure development priorities was the development of a 35,000 megawatts electricity project. The government committed to providing 35,000 megawatts of electricity from 2014 to 2019 . The data shows that the 35,000 MW electricity development program used a mix of energy resources. From the total energy resources, the project used $60 \%$ of its energy from coal, $35 \%$ from other primary sources of energy (gas, oil, etc.), and the rest from new and renewable energy (5\%) (Directorate General of Electricity, 2017).

The use of coal as a primary energy source for the national electricity project has been criticized by many. This is because it conflicts with the government's commitment to 
reducing its $\mathrm{CO}_{2}$ emissions by $29 \%$ by 2030 , has pledged to the UNFCCC. It has been estimated that the current fuel mix will increase $\mathrm{CO}_{2}$ emissions from 211 million tonnes in 2016 to 395 million tonnes in 2025 . Out of 395 million tonnes of such emissions, 317 million (80\%) comes from coal-burning (Ministry of Energy and Mineral Resources, 2016).

The selected Indonesian stakeholders believed that, while climate policy is important for reducing GHG emissions, it could not be implemented at the current time (at the time of the interview). They also believed that economic development could cause negative environmental impacts. However, Indonesia is at a stage of development in which the focus on development is beyond environmental concerns, and there is no consideration of skipping or leapfrogging this stage (Walker 1989). The key development policies should thus be focused on infrastructure investment, employment, and reducing poverty and inequality. With an abundance of natural resources, economic development has relied heavily on natural resource exploitation. Therefore, climate policy is considered by the Indonesian stakeholders to be incompatible with development and is placed at the bottom of the list of Indonesian development priorities.

\section{CONCLUSION AND FURTHER RESEARCH}

This paper establishes the perspectives of the selected Indonesian stakeholders in relation to the introduction of a carbon tax within the national development agenda. While the government of Indonesia acknowledges the importance of climate policies for reducing GHG emissions, the Indonesian stakeholders highlight that the government has prioritized economic development on the national agenda. This has been underpinned by the fact that the development planning agenda of the government has been focusing on the acceleration of infrastructure development. The focus on economic development is not considered compatible with environmental and climate mitigation efforts. The policymakers do not take environmental impacts from the development programs into account. As a result, climate policy initiatives have been given a lower priority in the development agenda. The Indonesian stakeholders accept the impacts of climate change and have created institutions to mitigate these impacts. However, there is an unresolved incompatibility between the national development agenda and meaningful climate change mitigation policies due to the dynamics of Indonesian governance. As a result, many government policies conflict with climate mitigation efforts, and Indonesia's ambitious target to reduce its GHG emissions remains questionable.

\section{REFERENCES}

Andrew, J., Kaidonis, M. A., \& Andrew, B., 2010. Carbon tax: Challenging neoliberal solutions to climate change. Critical Perspectives on Accounting, 21(7), pp. 611-618.

Bappenas, 2014. Rencana Pembangunan Jangka Menengah 2015-2019 (Vol. Book 1). Jakarta: Bappenas.

Baranzini, A., Goldemberg, J., \& Speck, S., 2000. A future for carbon taxes. Ecological Economics, 32(3), pp. 395-412.

Baranzini, A., Van den Bergh, J. C., Carattini, S., Howarth, R. B., Padilla, E., \& Roca, J., 2017. Carbon pricing in climate policy: seven reasons, complementary instruments, and 
political economy considerations. Wiley Interdisciplinary Reviews: Climate Change, 8(4), p. e462.

Baumol, W. J., \& Oates, W. E., 1971. The use of standards and prices for the protection of the environment. The economics of the environment (pp. 53-65): Springer.

Baylis, K., Fullerton, D., \& Karney, D. H., 2013. Leakage, Welfare, and CostEffectiveness of Carbon Policy. American Economic Review, 103(3), pp. 332-337.

Bureau, B., 2011. Distributional effects of a carbon tax on car fuels in France. Energy Economics, 33(1), pp. 121-130.

Charmaz, K., 2014. Constructing grounded theory. London: Sage.

Crowley, K., 2017. Up and down with climate politics 2013-2016: the repeal of carbon pricing in Australia. Wiley Interdisciplinary Reviews: Climate Change, 8(3), p. e458.

Dexter, A., 1970. Elite and Specialized Interviewing. Evanston, Ill. Northwestern UniversityPress.

Directorate General of Electricity., 2017. Development Report of 35,000 Electricity Generation. Retrieved from Jakarta:

Discount, Y., \& Eyland, T., 2011. Carbon control policies, competitiveness, and border tax adjustments. Energy Economics, 33(3), pp. 556-564

Feng, K., Hubacek, K., Guan, D., Contestabile, M., Minx, J., \& Barrett, J., 2010. Distributional Effects of Climate Change Taxation: The Case of the U.K. Environmental Science \& Technology, 44(10), pp. 3670-3676.

Fischer, C., \& Fox, A. K., 2012. Comparing policies to combat emissions leakage: Border carbon adjustments versus rebates. Journal of Environmental Economics and Management, 64(2), pp. 199-216.

Francis, K, Chapman, Y \& Whitehead, D., 2016, An overview of research theory and process, in Z Schneider, D Whitehead, G LoBiondo-Wood \& J Haber (eds), Nursing and midwifery methods and appraisal for evidence-based practice, Elsevier Australia, NSW, Australia, pp. 19-32.

Goulder, L. H., \& Schein, A. R., 2013. Carbon taxes versus cap and trade: a critical review. Climate Change Economics, 4(03), pp.

Greenwood, C., 2009. Green investing: towards a clean energy infrastructure. Opportunities Beyond Carbon, p. 210.

Guglyuvatyy, E., 2011. Assessing carbon tax and emissions trading as policy options for climate change mitigation in Australia. Sydney: University of New South Wales.

Harrison, K., 2010. The Comparative Politics of Carbon Taxation. Annu. Rev. Law Soc. Sci., $6(1)$, pp. 507-529.

Hourcade, J.C., and Robinson, J., 1996. Mitigating factors: assessing the costs of reducing GHG emissions. Energy Policy, 24(10-11), pp.863-873.

Hsu, S.L., 2012. The case for a carbon tax: Getting past our hang-ups to effective climate policy: Island Press.

Huang, Y., \& Pascual, U., 2018. Aid effectiveness for environmental sustainability. Washington: Palgrave Macmillan.

Jenkins, J. D., \& Karplus, V. J., 2017. Carbon Pricing under Political Constraints: Insights for Accelerating Clean Energy Transitions: Oxford University Press. 
Kerkhof, A. C., Moll, H. C., Drissen, E., \& Wilting, H. C., 2008. Taxation of multiple greenhouse gases and the effects on income distribution: A case study of the Netherlands. Ecological Economics, 67(2), pp. 318-326.

Lo, A., 2013. The Political Economy of Carbon Tax: International Practice and the Australian Model. Chinese Journal of Urban and Environmental Studies, 1(01). p. 1350007.

Mathur, A., \& Morris, A. C., 2014. Distributional effects of a carbon tax on broader U.S. fiscal reform. Energy Policy, 66(C), pp. 326-334.

Mildenberger, M., \& Leiserowitz, A., 2017. Public opinion on climate change: Is there an economy-environment tradeoff? Environmental Politics, 26(5), pp. 801-824.

Ministry of Energy and Mineral Resources., 2016. RTL 2016-2025. Jakarta: Kepmen ESDM No. 5899K/20/MEM/2016.

Ministry of Finance, 2009. Ministry of Finance Green Paper: Economic and Fiscal Policy Strategies for Climate Change Mitigation in Indonesia. Jakarta: Fiscal Policy Agency.

Nordhaus, W. D., 2013. The climate casino: Risk, uncertainty, and economics for a warming world: Yale University Press.

Nurdianto, D., \& Resosudarmo, B., 2016. The Economy-wide Impact of a Uniform Carbon Tax in ASEAN. Journal of the southeast Asian economies, 33(1), pp. 1-22.

Oates, W.E., 2000. From research to policy: the case of environmental economics. International Journal of Urban Sciences, 4(1), pp.1-15.

Poterba, J., 1991. Tax Policy to Combat Global Warming: On Designing a Carbon Tax. NBER Working Paper Series, 3649.

Rivers, N., 2010. Impacts of climate policy on the competitiveness of the Canadian industry: How big and how to mitigate? Energy Economics, 32(5), pp. 1092-1104.

Rozenberg, J., Hallegatte, S., Perrissin-Fabert, B., \& Hourcade, J.-C., 2012. Funding lowcarbon investments in the absence of a carbon tax. Climate Policy, 13(1), pp. 1-8.

Stern, N., 2008. The economics of climate change. American Economic Review, 98(2), pp. $1-37$.

Stiglitz, J. E., Stern, N., Duan, M., Edenhofer, O., Giraud, G., Heal, G., . . Pangestu, M., 2017. Report of the high-level commission on carbon prices. Carbon Pricing Leadership Coalition, 29.

Verde, S., \& Tol, R., 2009. The Distributional Impact of a Carbon Tax in Ireland. The Economic and Social Review, 40(3), pp. 317-338.

Walker, K.J., 1989. The state in environmental management: the ecological dimension. Political Studies, 37(1), pp.25-38.

Wang, Q., Hubacek, K., Feng, K., Wei, Y.-M., \& Liang, Q.-M., 2016. Distributional effects of carbon taxation. Applied Energy, 184, pp. 1123-1131.

White, R., 2012. NGO engagement in environmental law enforcement: critical reflections. Australasian Policing, 4(1), p. 4.

World Bank., 2017. Carbon Pricing Watch 2017. Washington DC: World Bank Group

Yusuf, A., \& Resosudarmo, B., 2015. On the distributional impact of a carbon tax in developing countries: the case of Indonesia. The Official Journal of the Society for Environmental Economics and Policy Studies / The Official Journal of the East Asian Association of Environmental and Resource Economics, 17(1), pp. 131-156. 